\title{
Fragipan Horizons: Definition, Properties, Genesis, and Influence on Soil Behavior
}

\author{
Michael Aide \\ Department of Agriculture, Southeast Missouri State University, Cape Girardeau, MO, USA \\ Email: mtaide@semo.edu
}

How to cite this paper: Aide, M. (2021) Fragipan Horizons: Definition, Properties, Genesis, and Influence on Soil Behavior. Agricultural Sciences, 12, 1490-1507. https://doi.org/10.4236/as.2021.1212095

Received: November 25, 2021

Accepted: December 20, 2021

Published: December 23, 2021

Copyright (c) 2021 by author(s) and Scientific Research Publishing Inc. This work is licensed under the Creative Commons Attribution International License (CC BY 4.0).

http://creativecommons.org/licenses/by/4.0/ (c) (i) Open Access

\begin{abstract}
Many Missouri forest soils exhibit fragipans, which influence soil productivity, ecosystem services and land management. Fragipan bearing soils tend to occur where loess thickness is moderate (1 to 2 meters) or where the soil profile exhibits evidence of mass wasting of weathered limestone residuum. Consensus is consolidating around the self-weight collapse of loess and residuum after repeated wetting and desiccation. The use of gravel as an indicator of parent material differences and its correlation with fragipan development is not perfectly aligned, thus although most fragipans do exhibit a bisequal soil profile, the placement of the lithologic discontinuity is difficult given mass wasting, eluviation-illuviation, side slopes, and other soil processes that contribute to increasing the bulk density and conferring strength. Fragipan genesis is evolving; however, research involving Ecosystem Site Descriptions are a fusion of a land parcel's soil properties, vegetational community, hydrology, and climate to guide land management. Ecological Site Descriptions associated with fragipan bearing soils are necessary, especially when making land management decisions.
\end{abstract}

\section{Keywords}

Fragipan, Soil Genesis, Soil Taxonomy, Forest Soils, Loess

\section{Introduction}

Soils with fragipans impose unique influences on landscape hydrology and plant growth. Fragipans are considered restrictive horizons that inhibit root penetration and water percolation. Fragipan-bearing soils are common and frequently associated with loess mantles of 1-to-2-meter thickness; however, fragipan-bearing soils may occupy landscapes where loess is very thin or absent [1]. No fragipans have been documented in thick loess deposits; however, some soils developed in 
thick loess may exhibit fragic properties [1] [2] [3]. The Missouri Ozarks upland and border regions are dominated by Alfisols and Ultisols across the uplands, with Entisols and Inceptisols common in the bottomlands. Fragipan horizons are almost exclusively associated with the upland Alfisols and Ultisols.

Ecological Site Descriptions provide land managers with a necessary and consistent context to evaluate land parcels for their land-use suitability and their capability to respond to different management activities or disturbance processes. Ecological Site Descriptions provide 1) site characteristics (physiographic, climate, soil, and water features, 2) plant communities (plant species, vegetation states, and ecological dynamics), 3) site interpretations (management alternatives) and 4) supporting documentation (cooperating federal and state agencies, relevant literature, information, and data sources). Integral to the usage of Ecological Site Descriptions is a model showing the primary vegetational state and transitional factors responsible for land usage and/or disturbed vegetational states.

The objectives of this manuscript are: 1) to describe the general soil description of a typical fragipan-bearing soil in the State of Missouri, 2) to provide an understanding of the research status of fragipans, and 3) to estimate the future research needs to understand fragipan genesis, fate, and influence on ecosystem services.

\section{Climate, Physiography, and Geology of the Salem Plateau Province}

The Salem Plateau, within the Ozark Plateau, has an aerial extent of $70,400 \mathrm{~km}^{2}$, occupying a large portion of southern Missouri and northern Arkansas. A structural dome underlies much of the Salem Plateau, with the St. Francois Mountains just east of a central highland. Precambrian felsics (primarily granites and rhyolites) occupy the St. Francois Mountains, with gravelly and non-gravelly limestones and dolomites of Cambrian and Ordovician age covering the remainder of the region. Some small areas present Mississippian and Pennsylvanian rocks, typically composed of fine-to-coarse grained limestones and cherty limestones [4]. The region's land use is primarily pasture and oak-hickory forest (Quercus-Carya), with some cropland on comparatively level plateaus and bottomlands.

The Salem Plateau's typical mean annual temperatures range from $13^{\circ} \mathrm{C}$ to $16^{\circ} \mathrm{C}\left(56^{\circ} \mathrm{F}\right.$ in the northern portion and $60^{\circ} \mathrm{F}$ in the southern portion). And the mean annual precipitations range from 1.06 to 1.12 meters (42 to 44 inches), reflecting a humid, continental climate. The April to September precipitation ranges from $0.59 \mathrm{~m}$ ( 22 inches) in the northeastern portion to $0.66 \mathrm{~m}$ ( 26 inches) in the southwestern portion, reflecting a strong seasonality. The estimated mean annual evapotranspiration rates are $0.76-0.89 \mathrm{~m} \cdot \mathrm{yr}^{-1}\left(30-35 \mathrm{in} \cdot \mathrm{yr}^{-1}\right)$ [4].

Muhs et al. [5] surveyed literature to assess the Peoria loess deposition rates during the last glacial maximum. Peoria loess was documented to have mass accumulation rates ranging from of maximum estimated rate in Nebraska of 
$17,500 \mathrm{~g} \cdot \mathrm{m}^{-2} \cdot \mathrm{yr}^{-1}$ to many other sites showing accumulation rates near 1500 $\mathrm{g} \cdot \mathrm{m}^{-2} \cdot \mathrm{yr}^{-1}$. The Peoria loess was documented to have 1) commonly a silt loam texture, 2) a clay mineralogy largely composed of kaolinite, hydrous mica (illite), vermiculite (hydroxy-Al interlayered vermiculite) and smectite, and 3) evidence of post aeolian deposition of reworking and solifluction $\left(21,000-16,500{ }^{14} \mathrm{C}\right.$ years before present).

\section{Fragipan Definition and Classification}

The Keys of Soil Taxonomy [6] list specific required characteristics for fragipans: "To be identified as a fragipan, a layer must have all of the following characteristics: 1) the layer is $15 \mathrm{~cm}$ or more thick; and 2) the layer shows evidence of pedogenesis within the horizon or, at a minimum, on the faces of structural units; and 3) the layer has very coarse prismatic, columnar, or blocky structure of any grade, has weak structure of any size, or is massive. Separations between structural units that allow roots to enter have an average spacing of $10 \mathrm{~cm}$ or more on the horizontal dimensions; and 4) air-dry fragments of the natural soil fabric, 5 to $10 \mathrm{~cm}$ in diameter, from more than 50 percent of the layer slake when they are submerged in water; and 5) the layer has, in 60 percent or more of the volume, a firm or firmer rupture-resistance class, a brittle manner of failure at or near field capacity, and virtually no roots; and 6) the layer is not effervescent (in dilute $\mathrm{HCl}$ )". This definition does not mention that fragipans frequently exhibit an elevated bulk density, redoximorphic surfaces, grayish colors, and clay films within pores or along ped faces.

\section{Recent Literature Resenting a Knowledge Base for Fragipan Genesis and Ultimate Fate (Haploidization)}

Olson and Hole [7] documented fragipan bearing soils in northeastern Wisconsin developed in glacial outwash and till. The typical pedon exhibited an upper sequum (Spodosol) and a lower sequum (fragipan and sandy outwash). The polygonal and bleached faces in the lower sequum may have formed as desiccation cracks during a comparatively warm and dry period 6000 to 4000 years ago. Eluviation from the upper sequum supported the higher bulk density. The lack of sufficient clay and root activity in the cold climate supported fragipan preservation.

Hammer [8] observed that forest soils in the Missouri Ozarks exhibit soil profile morphology patterns across the landscape. These patterns are typically related to topography, geologic, and geomorphic features; however, these patterns are sometimes difficult to discern because of site variability attributed to mass wasting, tree throw and micro-relief. In Indiana, Harlan and Franzmeier [9] documented that thick loess materials greater than 2-meter yield soils have an A-Bt-C horizon sequence, whereas the thinner loess materials ( 1 to 2 meter) produce soils having an A-Bt-E-Bx horizon sequence. Soils with less than one meter of loess have Bt horizons in both loess and residuum and usually do not 
exhibit fragipans.

Bockheim and Hartemink [10] examined 362 pedons with fragipans in the Natural Resources Conservation Service SSURGO database and USA case studies. Fragipans occur in Alfisol, Ultisol, Inceptisol, and Spodosol orders. Fragipan bearing soils generally have silty or loamy particle-size classes, udic or aquic soil-moisture regimes and a mixed mineralogy class. The most extensive areas having fragipans include the southern Mississippi River valley and the central-southern Appalachian Mountains and occur primarily in lower, moderately well-drained topographic positions. Bockheim and Hartemink [11] also examined soils having argillic, kandic and natric horizons, noting that in humid climates the argillic horizon requires approximately 12,000 years to develop, suggesting stable landscapes. Smith and Callahan [12] investigated South Carolina Upper Coastal Plain soils with firm, dense Bx horizons that are brittle, have bleached prisms and high bulk densities. The Fe-oxyhydroxide contents are highest in the $\mathrm{Bt}$ or $\mathrm{Bx}$ horizons and parallel the clay content distribution. Micromorphological examinations show dense packing of quartz skeleton grains and few voids in the $\mathrm{Bt}, \mathrm{Bx}$, and $\mathrm{C}$ horizons. Illuviation of iron-coated argillans is common to abundant in the $\mathrm{Bt}$ and $\mathrm{Bx}$ horizons. Hydroxy-Al interlayered vermiculite and kaolinite are the dominant clay minerals in the epipedons, with hydroxy-Al interlayered vermiculite showing a content decline with increasing soil depth and kaolinite showing increasing abundances with increasing soil depth.

Lindbo and Veneman [13] reviewed fragipan research originating in the northeastern USA. The presence of fragipan-bearing soils influenced the soil hydrology, morphology, and land use. Research arising from soils developed on dense basal tills are no longer recognized as having fragipans, because the fragipan properties are now assumed to be inherited rather than pedogenic. Research arising from soils developed on colluvium, alluvium, terraces, and coastal plain landscapes tend to exhibit bleached prism faces and are largely confined to soils having moderately-well to somewhat poorly-drained profiles. Other common fragipan features include: 1) high and low chroma redoximorphic features, 2) clay coatings, 3) vesicular pores, 4) massive to platy structures, 5) high bulk densities (1.65 to $\left.2.15 \mathrm{Mg} \cdot \mathrm{m}^{-3}\right), 6$ ) slaking in water, and 7) clay bridges.

Subsequently, Lindbo et al. [14] evaluated fragipan soils in the Lower Mississippi River Valley. A series of Typic Fragiudalfs and Glossic Fragiudalfs exhibited vertical gray seams and associated redoximorphic features. Lindbo et al. [15] further examined Glossic Fragiudalfs in the silty uplands of the lower Mississippi River Valley. These soils have fragipans within $100 \mathrm{~cm}$ of the surface and exhibit bleached coatings (albic material) along primary ped faces, indicating fragipan degradation. Concentrations of Fe-Mn nodules occur in horizons above the fragipan, suggesting fluctuating soil water conditions. Micromorphological observations suggested the nodules formed from the degradation of Btx materials to albic materials (E' material). 
Franzmeier et al. [16] summarized research largely performed in Kentucky, Ohio, Indiana, and Missouri, with some research from Illinois, Michigan, Wisconsin, and Kansas. Fragipan soils are associated with parent materials that include 1) loess, 2) glacial till, 3) weathered clastic rocks, and 4) residuum from weathered limestone and dolomite. Most of the examined pedons exhibited a $\mathrm{Bx}$ (Btx) horizon underlying a Bt horizon. Frequently an E or E' horizon was evident between the $\mathrm{Bt}$ and $\mathrm{Btx}(\mathrm{Bx})$ horizons. Most of the fragipans were 0.75 to 2.5 meters below the soil surface. The authors proposed that weathering in the $\mathrm{Bt}$ horizon provided soluble $\mathrm{H}_{4} \mathrm{SiO}_{4}$ to support Si-bonding in the fragipan.

Szymański and Skiba [17] evaluated the genesis and evolution of fragipan horizons in Albeluvisols of the Carpathian Foothills. They provided micromorphological evidence that fragipan genesis was related to lessivage. Vertical cracks and bleached tongues along the surfaces of the vertical cracks indicated fragipan degradation, a feature attributed eluviation of weathering products having shrink-swell capacity. Nikorych et al. [18] observed Ukrainian Albeluvisols and documented that the abundance of clay coatings, clay infillings, and iron-enriched clay cutans suggest clay and dissolved Fe lessivage from upper soil horizons into the fragipan horizons was important to fragipan genesis. Void filling in the Btx horizon reduced porosity and slowed the saturated hydraulic conductivity. Shrink-swell clay mineral enrichment of the fragipan is partially responsible for fragipan degradation. During episodes of wetting and drying, vertical cracks form having bleached tongues.

Falsone and Bonifacio [19] presented evidence that low water permeability and high bulk density were linked to a porous clay packing phase and an extremely dense packing of silt and sand. Bryant [20] investigated the relationships in fragipans involving high bulk density, close-packing of grains, and coarse prismatic structures. Bryant proposed that the initial desiccation process of a moist soil mass could initiate the high bulk density, especially in soil horizons having a low coefficient of linear extendibility. The self-weight collapse of sediment and the subsequent ripening are postulated as essential for fragipan development.

Smalley and Marković [21] defined hydroconsolidation as the collapse of loess ground structure under the influence of loading and wetting. In soils derived from loess, Smalley et al. [22] proposed three stages associated with fragipan horizon formation: 1) loess deposition, 2) a collapse stage which witnesses soil structure deformation under loading and wetting, and 3) cyclic drying episodes with contraction produce the characteristic cracking patterns. Assallay et al. [23] proposed that fragipan formation resulted in soil structure collapse while water saturated and when overburdened with soil forming materials. The likelihood of structural collapse is somewhat dependent on clay content, with loess typically having clay contents suitable for experiencing structural collapse. The resultant structural collapse results in an increase in bulk density and corresponding loss of pore space when water saturated [21]. 
James et al. [24] investigated fragipan bearing soils on broad ridgetops of the Springfield Plateau in southwestern Missouri. The landscape is covered with a 1 m thick silty mantle of late Wisconsinan loess overlying an erosional lag concentrate and cherty limestone residuum. A composite paleosol developed in the erosional lag concentrate and cherty limestone residuum, which was then bonded to the overlying soil horizons developed in the silty mantle. The composite paleosol was acidic and highly weathered with clay and silt perceived to have illuviated from the loess into the underlying paleosol. The fragipan formed in the erosional lag concentrate, where micromorphological evaluation exhibited close packing of particles within the fragipan. Aide et al. [25] in the Missouri Ozarks examined two Typic Fragiudult pedons formed in loess, colluvial material from dolomitic residuum, and dolomitic residuum. Clay illuviation into the fragipan suggested that weathered soil material from the upper sequum impacted fragipan expression. It was proposed that the fragipan is a colluvial relic feature and that hydroconsolidation has contributed to fragipan development.

Smeck et al. [26] reviewed soil research involving fragipans in Ohio, Indiana, and Iowa. They proposed that fragipans tend to form at lithological or chronological discontinuities. In southern Illinois, Wilson et al. [27] examined nine pedons having fragipan properties spanning across two catenas in southern Illinois. Loess thickness ranged from approximately 2 to $4 \mathrm{~m}$ and fragic soil properties were observed in the argillic horizons on side slope and head slope positions. Soil horizons meeting fragipan criteria ranged in soil depth from 140 to $175 \mathrm{~cm}$. Discontinuities, verified by particle size analysis between the Peoria and Roxana loess, suggest that fragic soil properties are not always positioned at the discontinuity between loess deposits. Fragipans having the strongest expression occur where loess is approximately $2 \mathrm{~m}$ overlying less permeable material, suggesting that loess thickness does influence degree of development of fragic properties.

In Michigan, Weisenborn and Schaetzl [28] observed bisequal soils, where the upper sequum was associated with Spodosol formation and the lower sequum was associated with argillic (Bt) horizon development. Protofragipans and fragipans exhibiting clay coatings and bridging were observed in the lower sequum. Weisenborn and Schaetzl [29] developed the Michigan Model of Fragipan Evolution (MMFE), which involved collapse of wet parent materials and intergrain bridging in the collapsed zone, Later, amorphous bonding agents were proposed to precipitate and effectively add strength to the fragipan. Fragipan degradation is initiated with a water saturation zone above the fragipan where translocation of materials to the fragipan was proposed.

Karathanasis [30] proposed that solution chemistry and mineralogical compositions support the premise that Si-rich aluminosilicates with a Si molar fraction ranging from 0.58 to 1.0 act as binding agents, which contribute brittleness and a hard consistency when dry. Karathanasis [31] employed selective chemical extractions to assess non-crystalline $\mathrm{Si} / \mathrm{Al}$ ratios in fragipan horizons and observed that these $\mathrm{Si} / \mathrm{Al}$ ratios correlated well with reduced $\mathrm{pH}_{4} \mathrm{SiO}_{4}$ solute func- 
tions, suggesting Si was involved in synthesis of fragipan binding agents. Harlan et al. [32] proposed that soluble silica, originating from feldspar and phyllosilicate weathering percolates and precipitates, possibly with aluminum hydrous oxides, on clays. The resulting silica or aluminosilicate precipitates act as cementing agents to confer brittleness in fragipans.

Duncan and Franzmeier [33] demonstrated that fragipan's which exhibited molar $\mathrm{Si} /(\mathrm{Si}+\mathrm{Al})$ ratios of less than 0.5 did not reveal any significant correlation with soil rupture strength; however, in fragipan horizon's where the molar $\mathrm{Si} /(\mathrm{Si}$ $+\mathrm{Al}$ ) ratio was greater than 0.5 , the correlation with rupture strength was significant. In Indiana, Sangamon paleosols are covered by Peoria Loess and where the loess is more than about $2.5 \mathrm{~m}$ the modern soil profile formed in loess, and where the loess mantle is less than $2.5 \mathrm{~m}$ the modern soil and the paleosol are welded or contiguous [34]. When compared to the overlying Bt horizons, fragipans, have higher smectite and free silica contents and greater exchangeable $\mathrm{Mg} / \mathrm{Ca}$ ratios. Steinhardt and Franzmeier [35] documented that the $\mathrm{SiO}_{2}$ contents reached a maximum in the fragipan horizons.

\section{The Status of Soils with Fragipans in Missouri}

Table 1 lists selected Missouri soils that have a fragipan and their taxonomic classification. Ultisols and Alfisols orders possess fragipans, with the majority having either udic or aquic moisture regimes at the suborder level. The most common great group classifications include Paleudults, Fragiudults, and Fragiudalfs, with a few series represented as Fragiaqualfs. Table 2 lists selected fragipan-bearing Missouri soils and their parent materials and Table 3 lists the drainage class and landform setting.

A typical fragipan containing soil in Missouri rests on a rolling to hilly forested landscape and exhibits A-E-Bt-2Btx-3Bt horizon sequences. The silt loam A horizon overlies a silt loam E horizon, generally establishing an ochric or mollic epipedon. The generally silty clay loam argillic horizon (Bt) shows few faint clay films to many distinct/prominent clay films (argillans) indicating clay eluviation-illuviation. Most pedologists consider the A-E-Bt horizons to be developed in Peoria loess or silty materials derived from mass wasting. The Bt horizon generally ranges from strongly acid to extremely acid. The upper sequum typically has a mixed clay mineralogy, composed of hydroxy- $\mathrm{Al}$ interlayered vermiculate and kaolinite, with hydrous mica and smectite (montmorillonite) [1] [12] [25] [30]. Extensive soil mapping frequently locates fragipan bearing soils on narrow to broad ridgetop positions, with non-fragipan bearing soils on stepper sideslope positions.

Many Missouri pedologists consider the lower sequum to be composed of clay materials eluviated from the upper sequum and material derived directly from limestone residuum (numerous personnel communications). Some pedologists have suggested that older Roxana loess may be present in some fragipan horizons; however, documentation of these ideas has proven difficult to verify. The presence 
of gravel reflects the weathering of limestone residuum or mass wasting of limestone residuum having embedded cherty gravels or cobbles. The mixed clay

Table 1. Selected Missouri soils that have a fragipan and their taxonomic classification.

\begin{tabular}{|c|c|}
\hline Aslinger & Fine-loamy, mixed, active, mesic Fragiaquic Paleudults \\
\hline Bado & Fine, mixed, active, mesic Typic Fragiaqualfs \\
\hline Bahner & Fine, mixed, active, mesic Mollic Paleudalfs \\
\hline Captina & Fine-silty, siliceous, active, mesic Typic Fragiudults \\
\hline Celt & Fine, mixed, active, mesic Aquic Fragiudults \\
\hline Cornwall & Fine-silty, mixed, active, mesic Fragiaquic Paleudults \\
\hline Cotton & Fine, smectitic, mesic Fragiaquic Hapludalfs \\
\hline Creldon & Fine, mixed, active, mesic Oxyaquic Fragiudalfs \\
\hline Delassus & Fine-loamy, mixed, active, mesic Typic Fragiudults \\
\hline Firebaugh & Fine-loamy, mixed, active, mesic Fragiaquic Paleudults \\
\hline Friendley & Fine, mixed, active, mesic Fragiaquic Hapludalfs \\
\hline Gerald & Fine, mixed, active, mesic Aeric Fragiaqualfs \\
\hline Hildebrecht & Fine-silty, mixed, active, mesic Oxyaquic Fragiudalfs \\
\hline Hoberg & Fine-loamy, siliceous, active, mesic Oxyaquic Fragiudalfs \\
\hline Hobson & Fine-loamy, siliceous, active, mesic Oxyaquic Fragiudalfs \\
\hline Hogcreek & Fine-loamy, siliceous, active, mesic Typic Fragiudults \\
\hline Jonca & Fine-loamy, mixed, active, mesic Oxyaquic Fragiudalfs \\
\hline Keeno & Loamy-skeletal, siliceous, active, mesic Oxyaquic Fragiudalfs \\
\hline Killarney & Loamy-skeletal, mixed, active, mesic Typic Fragiudults \\
\hline Lebanon & Fine, mixed, active, mesic Typic Fragiudults \\
\hline Loring & Fine-silty, mixed, active, thermic Oxyaquic Fragiudalfs \\
\hline Maplewood & Fine, mixed, active, mesic Fragiaquic Paleudalfs \\
\hline Needleye & Fine-silty, mixed, active, mesic Aquic Fragiudults \\
\hline Nicholson & Fine-silty, mixed, active, mesic Oxyaquic Fragiudalfs \\
\hline Nixa & Loamy-skeletal, siliceous, active, mesic Glossic Fragiudults \\
\hline Paintbrush & Fine-loamy, mixed, active, mesic Fragiaquic Paleudalfs \\
\hline Plato & Fine, mixed, active, mesic Aquic Fragiudalfs \\
\hline Scholten & Loamy-skeletal, siliceous, active, mesic Typic Fragiudults \\
\hline Tonti & Fine-loamy, mixed, active, mesic Typic Fragiudults \\
\hline Union & Fine, mixed, active, mesic Oxyaquic Fragiudalfs \\
\hline Viraton & Fine-loamy, siliceous, active, mesic Oxyaquic Fragiudalfs \\
\hline Wilderness & Loamy-skeletal, siliceous, active, mesic Oxyaquic Fragiudalfs \\
\hline Wrengart & Fine-silty, mixed, active, mesic Fragic Oxyaquic Hapludalfs \\
\hline Yelton & Fine-loamy, siliceous, active, mesic Typic Fragiudults \\
\hline
\end{tabular}


Table 2. Selected Missouri soils that have a fragipan and their parent materials.

\begin{tabular}{|c|c|}
\hline Aslinger & loamy colluvium and loamy or clayey alluvium \\
\hline Bado & thin mantle of loess over clayey residuum from cherty limestone/dolomite \\
\hline Bahner & thin mantle of loess and cherty dolomite residuum \\
\hline Captina & thin mantle of silt over limestone, cherty limestone/dolomite colluvium/residuum \\
\hline Celt & loess or silty colluvium over cherty residuum \\
\hline Cornwall & loess or silty sediments and valley fill materials. \\
\hline Cotton & loess and the underlying residuum from cherty limestone \\
\hline Creldon & thin mantle loess, colluvium, and loamy to clayey cherty limestone residuum \\
\hline Delassus & loess mixed with slope alluvium and residuum from igneous rocks \\
\hline Firebaugh & thin layer loess/silty sediment and loamy and clayey cherty dolomite \\
\hline Friendly & thin mantle of loess over loamy and clayey limestone residuum \\
\hline Gerald & thin mantle of loess or loamy colluvium over cherty limestone residuum \\
\hline Hildebrecht & loess over residuum weathered from dolomite \\
\hline Hoberg & thin mantle of loess and the underlying residuum from cherty limestone \\
\hline Hobson & residuum from mixed sandstone and cherty limestone or cherty dolomite \\
\hline Hogcreek & hillslope sediments mixed with loess and the underlying colluvium \\
\hline Jonca & thin layer of loess, colluvium, and the underlying sandstone residuum \\
\hline Keeno & uplands formed in residuum from cherty limestone \\
\hline Killarney & slope alluvium with loess and the underlying slope alluvium or rhyolite residuum \\
\hline Lebanon & loess and the underlying cherty residuum on uplands \\
\hline Loring & loess on level to strongly sloping uplands and stream terraces \\
\hline Maplewood & thin mantle of loess, colluvium, over loamy and clayey limestone residuum \\
\hline Needleye & thin mantle of loess over residuum from limestone \\
\hline Nicholson & mantle of loess or silty material over residuum of limestone, calcareous shale \\
\hline Nixa & colluvium and loamy residuum weathered from cherty limestone \\
\hline Paintbrush & thin mantle of loess or colluvium over loamy and clayey limestone residuum \\
\hline Plato & loess and the underlying cherty residuum on uplands \\
\hline Scholten & colluvium and the underlying residuum from cherty limestone on uplands \\
\hline Tonti & residuum from cherty limestone \\
\hline Union & layer of loess that underlying clayey residuum from cherty limestone/dolomite \\
\hline Viraton & loess and the underlying cherty residuum or colluvium from limestone \\
\hline Wilderness & colluvium and the underlying residuum from cherty limestone \\
\hline Wrengart & oess and residuum from cherty limestone \\
\hline Yelton & thin mantle of loess over colluvium/alluvium from sandstone and cherty dolomite \\
\hline
\end{tabular}


Table 3. Selected Missouri soils that have a fragipan and their landform positions.

\begin{tabular}{|c|c|}
\hline Aslinger & very deep, moderately well-drained soils on terraces, and valley footslopes, \\
\hline Bado & poorly-drained soils \\
\hline Bahner & very deep, well-drained soils on uplands \\
\hline Captina & very deep, moderately well-drained soils on uplands \\
\hline Celt & very deep, somewhat poorly-drained soils on upland \\
\hline Cornwall & very deep, moderately well-drained soils on high terraces, valley footslopes \\
\hline Cotton & very deep, moderately well-drained, slowly permeable on uplands \\
\hline Creldon & very deep, moderately well-drained soils on uplands \\
\hline Delassus & deep and very deep, moderately well-drained soils \\
\hline Firebaugh & very deep, moderately well-drained soils \\
\hline Friendley & very deep, somewhat poorly-drained soils on uplands \\
\hline Gerald & very deep, somewhat poorly-drained soils on uplands \\
\hline Hildebrecht & very deep, moderately well-drained soils on interfluves and summit \\
\hline Hoberg & very deep, moderately well-drained soils \\
\hline Hobson & very deep, moderately well-drained soils on uplands \\
\hline Hogcreek & moderately deep, moderately well-drained soils formed in hillslope sediments \\
\hline Jonca & very deep, moderately well-drained soils on interfluves and summit \\
\hline Keeno & very deep, moderately well-drained soils on uplands \\
\hline Killarney & very deep, moderately well-drained soils on foot slopes in mountainous areas. \\
\hline Lebanon & very deep, moderately well-drained soils on uplands \\
\hline Loring & very deep, moderately well-drained level to strongly sloping uplands and terraces \\
\hline Maplewood & very deep, somewhat poorly-drained, slowly permeable soils on uplands \\
\hline Needleye & very deep, somewhat poorly-drained soils on uplands \\
\hline Nicholson & very deep, moderately well-drained soils on upland ridgetops \\
\hline Nixa & very deep, moderately well-drained, soils on upland ridgetops and sideslopes \\
\hline Paintbrush & very deep, moderately well-drained soils on uplands \\
\hline Plato & very deep, somewhat poorly-drained soils on uplands \\
\hline Scholten & very deep, moderately well-drained soils on uplands \\
\hline Tonti & very deep, moderately well-drained on uplands \\
\hline Union & very deep, moderately well-drained soils on uplands \\
\hline Viraton & very deep, moderately well-drained soils on broad ridges, foot slopes, terraces \\
\hline Wilderness & very deep, moderately well-drained soils on interfluves and shoulder \\
\hline Wrengart & very deep, moderately well-drained soils on interfluves and summit \\
\hline Yelton & very deep, moderately well-drained soils on ridges, high terraces, footslopes \\
\hline
\end{tabular}

mineralogy for the $2 \mathrm{Btx}$ horizons is like the upper sequum, with the lower sequum having slightly smaller quantities of hydroxy- $\mathrm{Al}$ interlayered vermiculate 
[25]. The clay separate of the 3Bt1 horizons are almost exclusively composed of kaolinite [25]. Of the series displayed in Tables 1-3, all are developed in limestone or dolomite residuum (2Bt or $3 \mathrm{Bt}$ ), except for Delassus (developed on igneous rock), Jonca (developed in weathered sandstone), Killarney (igneous residuum), Hogcreek (quartz bedrock) and Loring (colluvial or alluvial silty materials). Some series have an Ex-horizon in at least a few of the examined pedons: Delassus, Gerald, Hildebrecht, Hobson, Jonca, Lebanon, Nixa, Tonti, Viration, Wilderness, Yelton.

In addition to the rolling to hilly landscape, another typical Missouri fragipan landscape setting features broad and somewhat level interfluves, with numerous slide slopes establishing ephemeral to enduring surface drainages. As an example, the Jonca series occupy broad, interior interfluve positions, whereas the Lily (Fine-loamy, siliceous, semiactive, mesic Typic Hapludults) and Ramsey (Loamy, siliceous, subactive, mesic Lithic Dystrudepts) pedons occupy the sloping positions along the drainages. The Jonca series exhibits a very deep A-BA-Bt$2 \mathrm{Bt}-2 \mathrm{Btx}-3 \mathrm{Bt}$-sandstone sequence, whereas the moderately deep Lily series exhibits A-Bt-sandstone sequences, and the shallow and very shallow Ramsey series exhibits A-E-Bw-sandstone sequences. The typically loamy texture of the $2 \mathrm{Btx}$ exhibits finer textured materials in $10-15 \mathrm{~mm}$ vertical cracks spaced about 30 $\mathrm{cm}$ apart, generating very coarse prismatic structures with massive interiors. A few fine roots are present along vertical cracks and clay films line channels and cavities. A thin loess mantle extends across the interfluve position and appears absent on the sidelobes, most likely a consequence of ancestral erosion. The stable landscape of the interfluve permits an approximately two-meter-thick loess mantle, which appears to be the optimum loess thickness for fragipan formation [33]. The Lily and Ramsey pedons lack any evidence of loess as a parent material.

\section{Fragipan Genesis and Our Current Knowledge Status}

Any competent fragipan development model necessarily must address the evolution of the fragipan's physical and morphological properties, including 1) an increased bulk density, 2) massive or prismatic structure, 3) clay infilling coupled with silt and sand dense packing, and 4) exhibit a brittle consistence at field capacity and a hard consistence when dry. Additionally, in Missouri, the recognized soil series having fragipans typically do not develop in thick loess deposits or very thin loess deposits, which was previously observed in other regions [9] [16] [26].

Weisenborn and Schaetzl [29] provided an evolutionary scenario for fragipan development, concentrating on northern Michigan soils, but applicable elsewhere. In their model of fragipan development they assert that the necessary initial pre-conditions include: 1) alternating wet-dry conditions, 2) a leaching soil environment, 3) sufficient soil acidification to degraded carbonate minerals, and 4) lessivage. Lessivage would require soil acidification and sufficient seasonal 
rainfall to remove calcium carbonate from the loess [31]. Subsequently, lessivage would require sufficient water percolation to assist in argillan development. Subsequent cyclic occurrences of desiccation and rewetting and associated soil acidification create the pre-conditions for protofragipan development. During wet conditions, Weisenborn and Schaetzl invoked the self-weight collapse phenomena to provide the initial close packing of the soil materials [29]. The hydroconsolidation process [21] [22], the erosional lag concentrate [24], and mass wasting to produce colluvial relics [25] are similar physical processes that may have relevance in supporting compaction, increased bulk density, and void packing.

Clay eluviation-illuviation and silt flows (sideslopes) continue the close packing process, development of clay bridges and pore linings and the advancement of void filling and greater bulk density attainment. Presumably associated with feldspar and phyllosilicate weathering, surplus non-crystalline bonding agents involving aluminosilicates $\mathrm{Al}_{2} \mathrm{O}_{3}$ and $\mathrm{H}_{4} \mathrm{SiO}_{4}$ form in the $\mathrm{Bt}$ horizon and non-crystalline enriched precipitates composed primarily of $\mathrm{H}_{4} \mathrm{SiO}_{4}$ in the fragipan. Continued close packing and earth material consolidation suppresses percolation and the episodic maintenance of water saturation at and above the fragipan. Fragipan degradation commences with perched water above the fragipan, leading to an Ex-horizon above the fragipan and along prism faces. The E'x or E' horizon (glossic) and the upper portion of the $2 \mathrm{Btx}$ horizon has weathered and degraded to albic materials [15].

Within a soil profile the abrupt presence of gravel may be an indicator for a lithologic discontinuity [36]. Some soil series have gravel in the $2 \mathrm{Btx}$ and $3 \mathrm{Bt}$ horizons; however, the overlying Bt horizons are gravel-free (at least less than 15\% pebbles to warrant the gravelly modifier). The Missouri soil series having gravel throughout the fragipan, and the underlying weathered residuum include: Aslinger, Celt, Firebaugh, Friendly, Hildebrecht, Hobson, Hogcreek, Lebanon, Needleye, Plato, Tonti, and Viraton. If the abrupt presence of gravel is the definitive indicator of a chronological lithologic discontinuity, then the soil series having gravel throughout the $2 \mathrm{Btx}$ horizons and $3 \mathrm{Bt}$ horizons infers that the fragipan formed from limestone residuum. However, Aide et al. [1] observed pedons of the Hildebrecht (Fragiudalfs) and indicated that the 2Bt and 2Btx horizons possessed a mixed clay mineralogy and the $3 \mathrm{Bt}$ horizons were almost exclusively kaolinitic. The abrupt and substantially different clay mineralogy would suggest that the fine earth fraction from the $2 \mathrm{Btx}$ horizons was not completely inherited from the underlying weather limestone residuum.

The overlying A-E-Bt sequence was presumed to be developed in loess or colluvial/alluvial additions of silty textured materials. Lessivage, from the orchic epipedon and argillic horizon into the weathered limestone residuum is substantial, especially arising during the last glacial maximum when solifluction and loess re-working were presumed to be very active [5]. The $2 \mathrm{Btx} 1$ horizons generally show 1) weak very coarse prismatic structure; 2) clay films on faces of 
prisms and silt coats on the upper parts of the prisms; 3) gray illuvial material in vertical cracks between prisms; and 4) iron oxyhydroxide depletions. These soil features are indicators that the upper and lower soil sequences have been blended to form one composite soil.

Some Missouri soil series exhibit some portion of the $2 \mathrm{Btx}$ horizon that is gravel-free and the underlying $3 \mathrm{Bt}$ horizons having gravel. Soil series featuring gravel-free fragipans and an underlying gravelly weathered limestone residuum include: Bado, Captina, Cornwall, Creldon, Gerald, Union, and Wrengart. If the abrupt presence of gravel is the definitive indicator of a chronological lithologic discontinuity, the soil series exhibiting at least a portion of the $2 \mathrm{Btx}$ sequence that is gravel-free has parent materials not exclusively associated with the underlying limestone residuum. As an example, the Union soil series has a silty clay Bt horizon and an underlying silt loam Btx1 horizon that gradually transitions to an extremely gravelly silt loam $2 \mathrm{Btx} 2$ horizon. The Bt and $2 \mathrm{Btx} 1$ horizons are thought to be formed in Peoria loess, whereas the $2 \mathrm{Btx} 2$ horizon and $3 \mathrm{Bt}$ horizon are formed in weathered limestone residuum. The Creldon series typically has a silty clay loam $2 \mathrm{Btx} 1$ and a very gravelly silty clay loam $2 \mathrm{Btx} 2$ and extremely gravelly silty clay $3 \mathrm{Bt}$ horizon sequence. The Creldon series was a soil selected for the James et al. [24] study, wherein the 2Btx horizon was presumed to be derived from mass wasting.

Soil series having gravel throughout their soil profile include Killarney, Nixa, Scholten, and Wilderness. Some soil series without any gravel in their soil profile include Delassus, Jonca, Loring, Nicholson, and Yelton. Obviously, using gravel to indicate lithologic discontinuities is not germane to fragipan-bearing soils lacking gravel or having gravel across all horizons of the soil profile.

\section{Importance Inferences from Soils Not Having Fragipans}

Soils not having fragipans that occur in association with fragipan bearing soils may provide information important to fragipan evolution. The Goss series (Clayey-skeletal, mixed, active, mesic Typic Paleudalfs) are very deep, well drained soils upland soils formed in colluvium and residuum weathered from cherty limestone or cherty dolomite. The typical Goss pedon has an A-E-2Bt-3Bt horizon sequence, where the ochric epipedon is gravelly silt loam and the argillic horizon is gravelly silty clay loam to gravelly clay. The loamy-skeletal Wilderness series (Fragiudalfs) occupy higher positions in the landscape and exhibit A-Bt-2Ex-2Btx-3Bt horizon sequences. The depth to the fragipan ranges from 0.38 to $0.74 \mathrm{~m}$ (15- 29 inches). Thus, these similar soils differ in the presence of sufficient loess or weathered limestone colluvium to form the fragipan. The Goss pedons transition from the ochric epipedons to the underlying clayey weathered limestone residuum, suggesting that colluvium accumulation lacked sufficient depth to support fragipan development.

The Rueter series (Loamy-skeletal, siliceous, active, mesic Typic Paleudalfs) consists of very deep, somewhat excessively-drained soils that formed in collu- 
vium and residuum from cherty weathered limestone. The soil horizon sequence is $\mathrm{A}-\mathrm{E}-\mathrm{Bt}-2 \mathrm{Bt}$, with the ochric epipedon having gravelly silt loam textures and the argillic horizon have gravelly silt loam textures $(\mathrm{Bt})$ that transition abruptly to gravelly clay textures $(2 \mathrm{Bt})$. The Rueter series occupy steep side slopes and narrow ridgetops [37]. The Clarksville series (Loamy-skeletal, siliceous, semiactive, mesic Typic Paleudults) are very deep, somewhat excessively-drained soils formed in colluvium from clayey-textured limestone residuum. The Clarksville series occupies steep side slopes and narrow ridgetops. The Clarksville series typically has an A-E-Bt-2Bt-3Bt horizon sequence, where the gravelly ochric epipedon and the gravelly $B t$ horizons have silt loam textures and the gravelly 2Bt-3Bt horizons have clay loam and clay textures. The Scholten series (Fragiudults) occupy gently sloping ridgetop positions and are formed in colluvium and the underlying weathered cherty limestone residuum. The A-E-Bt-2Btx-3Bt horizons sequence transitions from gravelly silt loam to gravelly clay at the 2Btx-3Bt abrupt and smooth boundary. Like the Goss-Wilderness series, the fragipan bearing Scholten soils occupy more stable upland ridgetop positions. Thus, topographic position is important in the evolution of these fragipan and non-fragipan bearing soils. There has been speculation among pedologists as to the distribution of loess across landscape positions, with a preference for loess accumulation on interfluve and ridgetop positions supporting fragipan formation.

\section{Fragipan-Bearing Soil and Their Relationships with Land Management}

In Missouri, soils having fragipans are common. Missouri, like other States, has supported the development of Ecological Site Descriptions [38]. An ecological site is defined as "a distinctive type of land based on recurring soil, landform, geological, and climate characteristics that differs from other kinds of land in its ability to produce distinctive kinds and amounts of vegetation and in its ability to respond similarly to management actions and natural disturbances" [39]. Ecological site descriptions are largely available for much of the woodlands and rangelands across Missouri; however, the development of ecological site descriptions continues and many are considered provisional (under review). Key features associated with ecological site descriptions include: 1) physiologic features, 2) climate descriptions, 3) water, soil, ecological dynamics, 4) interpretations. Interpretations include a detailed State and Transition diagram, depicting the reference state (vegetation that would occur without human intervention) and alternative states and the events or land management supporting state to state transition. An example of Reference State to State transition is "White Oak (Quercus alba)-Black Oak (Quercus velutina)" to "Timber Managed Mixed Oak Woodland" because of managed forest harvesting and fire suppression. The growth rates of these forest species are conditioned on the presence of a fragipan. As examples, the soil series and their specific ecological site descriptions are 
1) Gerald series and "claypan summit prairie", 2) Scholten series and "low-base chert upland woodland", 3) Tonti and Hildebrecht series and "Fragipan Upland Woodland", and 4) Killarney series and "Igneous Exposed Backslope Woodland".

\section{Future Research Needs to Elucidate Fragipan Genesis}

The understanding of fragipan evolution has implications for land management. Key research items for developing a competent understanding of fragipan genesis include:

1) Detailed investigations to determine the relationships between loess stratigraphy and soil fragipan distribution and properties,

2) Detailed investigations to determine the relationships between mass wasting and possible paleo-cryoturbation with fragipan development,

3) Determine clay mineral composition to better identify fragipan parent material origin,

4) Continue to investigate $\mathrm{H} 4 \mathrm{SO} 4$ as a bonding agent to confer fragipan strength,

5) Continue to evaluate the influence of fragipans on water relations and root distributions,

6) Employ micro-morphology descriptions to determine the pathways for eluviation-illuviation and other fabric properties important to fragipan genesis,

7) Identify and estimate the influence of fragipans on the soil's ecosystem service provisions.

\section{Conflicts of Interest}

The author has no conflict of interest.

\section{References}

[1] Aide, M.T., Brown, B. and Gregg, K. (1987) The Influence of Loess Thickness on Fragipan Expressions in St. Francois and Ste. Genevieve Co's, Missouri. Transactions of the Missouri Academy of Science, 22, 63-79.

[2] Ramson, M.D., Sneck, N.E. and Bigham, J.M. (1987) Stratigraphy and Genesis of Polygenetic Soils on the Illinoian Till Plain of South-Western Ohio. Soil Science Society of America Journal, 51, 135-141. https://doi.org/10.2136/sssaj1987.03615995005100010030x

[3] Lindbo, D.L., Rhoton, F.E., Bigham, J.M., Jones, F.S., Smeck, N.E., Hudnall, W.H. and Tyler, D.D. (1994) Bulk Density and Fragipan Identification in Loess Soils of the Lower Mississippi River Valley. Soil Science Society of America Journal, 58, 884-891. https://doi.org/10.2136/sssaj1994.03615995005800030036x

[4] Adamski, J.C., Petersen, J.C., Freiwald, D.A. and Davis, J.V. (1995) Environmental and Hydrological Setting of the Ozark Plateau Study Unit, Arkansas, Kansas, Missouri, and Oklahoma. Water Resources Investigations Report 94-4022. US Geological Survey, Earth Science Information Center, Denver.

[5] Muhs, D.R., Bettis, E.A., Roberts, H.M. and Wintle, A.G. (2003) Last Glacial Loess in the Conterminous USA. USGS Staff Published Research 180. 
https://digitalcommons.unl/usgsstaggpub/180

[6] Soil Survey Staff (2014) Keys to Soil Taxonomy. 12th Edition, USDA-Natural Resources Conservation Service, Washington DC.

[7] Olson, G.W. and Hole, F.D. (1967-1968) The Fragipan in Soils of Northeastern Wisconsin. Transactions of the Wisconsin Academy of Sciences, Arts and Letters, 56, 173-184.

[8] Hammer, R.D. (1997) Missouri Ozark Forest Soils: Perspectives and Realities. Proceedings of the Missouri Ozark Forest Ecosystem Project Symposium: An Experimental Approach to Landscape Research, St. Louis, 3-5 June 1997, 106-121.

[9] Harlan, P.W. and Franzmeier, D.P. (1977) Soil Formation on Loess in Southwestern Indiana: I. Loess Stratigraphy and Soil Morphology. Soil Science Society of America Journal, 41, 93-98. https://doi.org/10.2136/sssaj1977.03615995004100010028x

[10] Bockheim, J. and Hartemink A.E. (2013) Soils with Fragipans in the USA. Catena, 104, 251-256. https://doi.org/10.1016/j.catena.2012.12.001

[11] Bockheim, J.G. and Hartemink, A.E. (2013) Distribution and Classification of Soils with Clay-Enriched Horizons in the USA. Geoderma, 209-210, 153-160. https://doi.org/10.1016/j.geoderma.2013.06.009

[12] Smith, B.R. and Callahan, L.L. (1987) Soils with Bx Horizons in the Upper Coastal Plains of South Carolina. Soil Science Society of America Journal, 51, 158-164. https://doi.org/10.2136/sssaj1987.03615995005100010034x

[13] Lindbo, D.L. and Veneman, P.L.M. (1989) Fragipans in the Northeastern United States. In: Smeck, N.E. and Ciolkosz, E.J., Eds., Fragipans: Their Occurrence, Classification, and Genesis, Soil Sci. Soc. Am. Special Publication 24, Soil Science Society America, Madison, 11-31. https://doi.org/10.2136/sssaspecpub24.c2

[14] Lindbo, D.L., Rhoton, F.E., Bigham, J.M., Hudnall, W.H., Jones, F.S., Smeck, N.E. and Tyler, D.D. (1995) Loess Toposequences in the Lower Mississippi River Valley: I. Fragipan Morphology and Identification. Soil Science Society of America Journal, 59, 487-500. https://doi.org/10.2136/sssaj1995.03615995005900020032x

[15] Lindbo, D.L., Rhoton, F.E., Hudnall, W.H., Smeck, N.E., Bigham, J.M. and Tyler, D.D. (2000) Fragipan Degradation and Nodule Formation in Glossic Fragiudalfs of the Lower Mississippi River Valley. Soil Science Society of America Journal, 64, 1713-1722. https://doi.org/10.2136/sssaj2000.6451713x

[16] Franzmeier, D.P., Norton, L.D. and Steinhardt, G.C. (1989) Fragipan Formation in Loess of the Midwestern United States. In: Smeck, N.E. and Ciolkosz, E.J., Eds., Fragipans. Their Occurrence, Classification, and Genesis. Soil Science Society of America, Special Publication 24, Soil Science Society America, Madison, 69-97. https://doi.org/10.2136/sssaspecpub24.c5

[17] Szymański, W. and Skiba, S. (2011) Micromorphological Properties of the Fragipan Horizon in Albeluvisols of the Carpathian Foothills. Polish Journal of Soil Science, 44, 193-200. https://doi.org/10.1016/j.catena.2012.07.012

[18] Nikorych, V., Szymańsk, W., Polchyna, S. and Skiba, M. (2014) Genesis and Evolution of the Fragipan in Albeluvisols in the Precarpathians in Ukraine. Catena, 119, 154-165. https://doi.org/10.1016/j.catena.2014.02.011

[19] Falsone, G. and Bonifacio, E. (2009) Pore-Size Distribution and Particle Arrangement in Fragipan and Nonfragipan Horizons. Journal of Plant Nutrition and Soil Science, 172, 696-703. https://doi.org/10.1002/jpln.200800066

[20] Bryant, R.B. (1989) Physical Processes of Fragipan Formation. In: Smeck, N.E. and 
Ciolkosz, E.J., Eds., Fragipans. Their Occurrence, Classification, and Genesis, Soil Science Soc. Am. Special Publication 24, Soil Science Society America, Madison, 141-150. https://doi.org/10.2136/sssaspecpub24.c8

[21] Smalley, I.J. and Marković, S.B. (2014) Loessification and Hydroconsolidation: There Is a Connection. Catena, 117, 94-99.

https://doi.org/10.1016/j.catena.2013.07.006

[22] Smalley, I.J., Bentley, S.P. and Markovic, S.B. (2016) Loess and Fragipans: Development of Polygonal-Crack-Network Structures in Fragipan Horizons in Loess Ground. Quaternary International, 399, 228-233. https://doi.org/10.1016/j.quaint.2015.01.034

[23] Assallay, A.M., Jefferson, I., Rogers, C.D. and Smalley, I. (1998) Fragipan Formation in Loess Soils: Development of the Bryant Hydroconsolidation Hypothesis. Geoderma, 83, 1-16. https://doi.org/10.1016/S0016-7061(97)00135-3

[24] James, H.R., Ransom, M. and Miles, R. (1995) Fragipan Genesis in Polygenetic Soils on the Springfield Plateau of Missouri. Soil Science Society of America Journal, 59, 151-160. https://doi.org/10.2136/sssaj1995.03615995005900010024x

[25] Aide, M.T., Dunn, D. and Stevens, G. (2006) Fragiudults Genesis Involving Multiple Parent Materials in the Eastern Ozarks of Missouri. Soil Science, 171, 1-9. https://doi.org/10.1097/01.ss.0000227377.16697.50

[26] Smeck, N.E., Thompson, M.L., Norton, L.D. and Shipitalo (1989) Weathering Discontinuities: A Key to Fragipan Formation. In: Smeck, N.E. and Ciolkosz, E.J., Eds., Fragipans. Their Occurrence, Classification, and Genesis, Soil Science Society of America Special Publication 24, Soil Science Society America, Madison, 99-112. https://doi.org/10.2136/sssaspecpub24.c6

[27] Wilson, M.A., Indorante, S.J., Lee, B.D., Follmer, L., Williams, D.R., Fitch, B.C., McCauley, W.M., Bathgate, J.D., Grimley, D. and Kleinschmidt, K. (2010) Location and Expression of Fragic Soil Properties in a Loess-Covered Landscape, Southern Illinois, USA. Geoderma, 154, 529-543.

https://doi.org/10.1016/j.geoderma.2009.03.003

[28] Weisenborn, B.N. and Schaetzl, R.J. (2005) Range of Fragipan Expression in Some Michigan Soils. I. Morphological, Micromorphological, and Pedogenic Characterization. Soil Science Society of America Journal, 69, 171-178. https://doi.org/10.2136/sssaj2005.0178a

[29] Weisenborn, B.N. and Schaetzl, R.J. (2005) Range of Fragipan Expression in Some Michigan Soils: II. A Model for Fragipan Evolution. Soil Science Society of America Journal, 69, 178-187. https://doi.org/10.2136/sssaj2005.0178a

[30] Karathanasis, A.D. (1987) Mineral Solubility Relationships in Fragiudalfs of Western Kentucky. Soil Science Society of America Journal, 51, 474-481. https://doi.org/10.2136/sssaj1987.03615995005100020041x

[31] Karathanasis, A.D. (1989) Soil Solution Chemistry of Fragipans-Thermodynamic Approach to understanding Fragipan Formation. In: Smeck, N.E. and Ciolkosz, E.J., Eds., Fragipans. Their Occurrence, Classification, and Genesis, Soil Science Society of America Special Publication 24, Soil Science Society America, Madison, 113-139. https://doi.org/10.2136/sssaspecpub24.c7

[32] Harlan, P.W., Franzmeier, D.P. and Roth, C.B. (1977) Soil Formation on Loess in Southwestern Indiana: II. Distribution of Clay and Free Oxides and Fragipan Formation. Soil Science Society of America Journal, 41, 99-103.

https://doi.org/10.2136/sssaj1977.03615995004100010029x 
[33] Duncan, M.M. and Franzmeier, D.P. (1999) Role of Free Silicon, Aluminum, and Iron in Fragipan Formation. Soil Science Society of America Journal, 63, 923-929. https://doi.org/10.2136/sssaj1999.634923x

[34] Tremocoldi, W.A., Steinhardt, G.C. and Franzmeier, D.P. (1994) Clay Mineralogy and Chemistry of Argillic Horizons, Fragipans, and Paleosol B Horizons of Soils on a Loess-Thinning Transect in Southwestern Indiana, USA. Geoderma, 63, 77-93. https://doi.org/10.1016/0016-7061(94)90111-2

[35] Steinhardt, G.C. and Franzmeier, D.P. (1979) Chemical and Mineralogical Properties of the Fragipans of the Cincinnati Catena. Soil Science Society of America Journal, 43, 1008-1013. https://doi.org/10.2136/sssaj1979.03615995004300050039x

[36] Buol, S.W., Southard, R.J., Graham, R.C. and McDaniel, P.A. (2003) Soil Genesis and Classification. Iowa State Press (Blackwell Publishing Co.), Ames.

[37] Aide, M.T. (2021) Soil Genesis of Four Alfisols Established in Oak Hickory Forests along Drainages into the Mississippi River in Southeastern Missouri, USA. Geos cience and Environmental Protection, 9, 124-143. https://doi.org/10.4236/gep.2021.92008

[38] Aide, M.T., Braden, I.S. and Aide, C. (2021) Integrating Ecological Site Descriptions with Soil Morphology to Optimize Soil Management: Three Missouri Case Studies. IntechOpen, London. https://doi.org/10.5772/intechopen.97251

[39] USDA-NRCS Staff.

https://www.nrcs.usda.gov/wps/portal/nrcs/detail/national/landuse/rangepasture/?c $\underline{\mathrm{id}=\text { stelprdb1068392 }}$ 